\title{
Exploring the Link between Organizational Learning and Transformational Leadership: A Review
}

\author{
Ibrahim A. H. Mohamed ${ }^{1}$, Nuri Mohamedm M. Otman² \\ ${ }^{1}$ Department of Management, The Higher Institute of Tourism and Hospitality, Benghazi, Libya \\ ${ }^{2}$ Education Faculty, University Camilo José Cela, Madrid, Spain \\ Email: bofa200850@yahoo.com, normn8393@gmail.com
}

How to cite this paper: Mohamed, I.A.H. and Otman, N.M.M. (2021) Exploring the Link between Organizational Learning and Transformational Leadership: A Review. Open Access Library Journal, 8: e7242 https://doi.org/10.4236/oalib.1107242

Received: February 13, 2021

Accepted: May 23, 2021

Published: May 26, 2021

Copyright (c) 2021 by author(s) and Open Access Library Inc.

This work is licensed under the Creative Commons Attribution International License (CC BY 4.0).

http://creativecommons.org/licenses/by/4.0/

\begin{abstract}
This study highlights the relation between organizational learning and transformational leadership, recognizes the significance of transformational leadership and explores its association with organizational learning. Organizations can become more competitive by bridging the gap between the existing transformational leadership talents, skills and the organizational learning levels based on the leaders' commitment and dedication that gives a new life to an organization. Some leaders have better capabilities and capacities to make their organizations more competitive as compared to others, and they do so by focusing on important factors, which improve organizational learning. Their aim is reinforcement of transformational leadership and improving the organizational members' learning processes and competences to help them adapt to changes taking place in the business environment for achieving learning that results in organizational excellence. For exploring learning issues, results mentioned in the previous literature indicate that a positive relation exists between organizational learning and transformational leadership, while the former directly affects the development of creativity, skills, innovation, and capabilities.
\end{abstract}

\section{Subject Areas}

Management Organization

\section{Keywords}

Leadership, Transformational Leadership, Organizational Learning, Learned Organization 


\section{Introduction}

In the current post-modern business world, organizations are facing several challenges, which raised many questions on the inability of the traditional leadership styles to deal with issues and compete in today's business environment. Thus, now organizations need leaders instead of administrators. Leaders, who have strong motivation, can actually extend an organization's life or give a new life to it (Hogan and Kaiser, 2005) [1]. The literature has explored commonalities between transformational style of leadership and learning mainly because leaders, who have highly considerable influence and the ability to play a crucial role for enhancement of organizational learning. Many research articles have been published so far, which deal with organizational learning and leadership. In the leadership literature, leadership is treated as a fundamental claim; so, leaders' influence priorities and goal setting through motivating people, and also through enabling, inspiring, and creating a conducive psychological atmosphere (Bass, 1990) [2].

The organization act on the organization's behalf by analyzing, collecting, retrieving, disseminating, and storing information. It helps gathering and using the knowledge, which affects their performances and the overall organizational performance. In both academic and popular management literature, this concept has gained growing attention, and now, it is considered as a source of competitiveness.

Researchers have sufficiently emphasized organizational learning and its importance for "knowledge-creating organizations." Managers should first understand how a learning organization operates (Hübner, 1995) [3]. While initially exploring this vital area, managers and researchers have given remarkable attention to the topic of organizational learning. Although the number of writings has grown, field studies are limited on this topic.

Even now, there is no consensus on what is the nature of basic characteristics, which form an educated organization. It is a fact that today, we live in a world, which has witnessed progress and explored the factors of change for transformation almost in every walk of life, which have urged the organizations to find new competitiveness promoting methods, provide advantages for organizational survival in the market and to make it profitable by adapting to changes, which are taking place in the ways of doing business. Such changes are accelerated by post-modern knowledge, information and communication technology. Such methods are based on a primary conviction that learning is the key to perpetuate the efficiency and it assures administrative effectiveness. The only sustainable source of competitive advantage is continuous learning because the environment is rapidly changing, and it increases the organizational performance.

Organizations assure that their members are capable and willing to learn, after which, they can learn regardless of their ages and successfully adapt to new circumstances and market variables. Since every organization is subject to local as well as international economic pressures because of rapid globalization, they 
need to respond back. In the current business scenario, most of the organizations have already realized that organizational learning is a vital mechanism to achieve long-term organizational efficiency and success. In other words, it means that learning defines an organization's ability to exist and flourish in a rapidly changing situation (Prokesch, 1997) [4]. Organizational learning is the process to improve by which an organization itself over time through gaining experience and using it to create knowledge then transferred within the organization. (JacobBrix, 2017) [5]. The knowledge is asset a knowledge-based institution should have, therefore, must be the organization maintain this asset first, and how to use it to create value and achieve competitive advantage, so the apparent distinction between organizational learning and knowledge management has led to the creation of different leadership roles in the organizations, whereas learning officers focus on human relations and build on training, education, leadership development, and change management, while chief knowledge officers focus on information technology and build on knowledge worker productivity, knowledge repositories, and knowledge networks (Knopf \& Jeffrey, 2003) [6]. However, the process of learning to involves knowledge creation on many levels, such as the cognitive skills of knowing how and a coordination of the large motor skills of doing that lead to the discussion of knowledge creation. (JacobBrix, 2017) [5].

Therefore, it can be stated that organizational learning is the major output to a knowledge management process that supports organizational processes which will improvement over time then instils collaborative decision-making, and produce efficiencies in retrieving information. (Beverly Weed-Schertzer, 2020) [7]. The significance of research comes through the role of transformational leadership in improving organizational learning by supporting the processes of change which leads to intellectual amusement then creativity, innovation and the increase of self-confidence. Therefore, the objective of this study is to present a brief review of the relation between transformational leadership and organizational learning focusing on the findings of previous studies in the available literature.

\section{Literature Review}

\subsection{Leadership}

Basically, leadership specifies the role of individuals and defines the nature of influence depending on traits, group processes, goal achievement tools, and behaviors (Bass, 1990) [2]. Leadership experts and scholars presented several definitions of leadership; however, they have been unable to finalize any universally accepted definition; but still, it is true that leadership is significant for achieving competitive advantage (İşcana, Ersarı, and Naktiyokc, 2014) [8].

During the last three decades of leadership research, several researchers have analyzed transformational leaders' genders, types, behaviors, performances, and followers (Chatbury, Beaty, and Kriek, 2011) [9]. Scholars on this subject believe 
that management accomplishes business processes and fulfills organizational goals whereas leaders exert their social influence, and give a vision/purpose of change to their people (Zaleznik, 1977 [10]; Bedeian and Hunt, 2006 [11]).

Thus, both management and leadership are significant to facilitate organizational performance, which confirms the views of Yukl and Becker (2006) [12] who believe that leadership is a process of teaching and influencing others to understand how and why some goals and activities should be accomplished. It also means that it is a process of facilitating collective and individual efforts to understand and achieve shared organizational goals.

Moreover, we should focus on the abilities of people, capability of the leader, and the process of achieving the targets, which means that followers should fully understand the leadership process (House and Aditya, 1997) [13]. Practically, the definitions of leadership and management generally overlap; however, both of them are important to predict organizational learning (Vera and Crossan, 2004) [14]. They might be concerned with different styles of management when they overlap with leadership, which is also true in case of transactional leadership (Bass, 1985) [15]. Leaders' skills and behaviors are hardly focused on their own capabilities and roles, which give them sufficient importance.

During the last few decades, several leadership development theories were presented, which attempted to explain the leadership roles in complex environments; however, still there is a gap that should be filled and that is regarding the next generation of leaders, about which, there is no mature understanding (Dinh et al., 2014) [16].

\subsection{Leadership Theories}

Since leadership is a very popular subject of management and organizational behavior. According to Robbins (2003) [17], leaders motivate employees, guide them, select a very effective method to communicate, and solve issues. It is not easy to identify leadership because they do not emerge out of vacuum (Raes, Kyndt, Lismont, Decuyper, Demeyere, Van den Bossche, and Dochy, 2013) [18]. According to a research conducted by Zhang (2011) [19], leadership has more than 350 definitions. Leadership, whether formal or informal, influences people, which helps achieving objectives (O’Gorman and Robbins, 2012) [20].

An argument presented by Leithwood and Sun (2012) [21] shows that leadership is identifiable with several non-unified characteristics. Jiang, Wang, and Gu (2015) [22] suggested that leadership is vital for human survival; however, it is not a clear definition of leadership. In leadership theory, researchers have identified four more theories: behavioral leadership theory, trait theory, integrative leadership theory, and contingency leadership theory (Achua and Lussier, 2013) [23]. Following the same line of thought, Daft (2008) [24] has stipulated many major leadership theories:

1) Great man theory (1950-1990s): It recognizes that the leaders' traits include greatness, which clearly indicates that they are different as compared to the 
people, who do not have leadership qualities.

2) Trait's theories (1940s): They differentiate personality/personal traits of a leader; therefore, the most common leadership traits include reliability, honesty, extroversion, reliability, self-confidence, intelligence, aspiration, and knowledge to lead others (Yukl, 2011) [25].

3) Behavioral theories (1940-1950): They suggest that any person can become a good leader, given that he/she has appropriate behavior. They mentioned different styles, such as autocratic style, democratic style, and laissez-faire style, which were presented at the University of Iowa by three researchers Lippitt, Lewin, and White (1939) [26].

4) Individualized leadership theory (1960): It focuses on leader-follower relationship, which is termed as dyad that focuses on the leader-follower exchange relationship (Antonakis, Cianciolo, Sternberg, Bass, Bryman, \& Jackson, 2011) [27].

5) Contingency theories (1950s): They examine different situation-based leadership styles (Fiedler, 2015) [28].

\subsection{Transformational Leadership}

This terminology clearly indicates that it is about change or transformation of an organization, and for the first time, Burns (1978) presented this terminology. Since he was a political scientist, he changed it in a predominant organizational behavior theory, which defines transformational leadership as a method, through which, followers and leaders raised each other to higher moral and motivational levels (Barbuto, 1997) [29]. Moreover, this type of leaders empowers their followers, and engage them in creative and innovative processes, which foster growth and creative change rather than just maintaining status quo (Khanin, 2007) [30]. Yukl (2006) mentioned that transformational leaders inspire their followers, and ask them to forgo their personal self-interest for their organizations (Sadeghi and Pihie, 2012) [31].

Avolio and Bass (1995) [32] presented developed ideas and improved transformational leadership as a concept. This leadership form seeks to establish link between individual interests and collective interests, which allows followers to make efforts and achieve transcendental goals by improving their morale, performance, and motivation to handle different mechanisms (Odumeru and Ogbonna, 2013) [33]. According to Tichy and Devanna (1986) [34], transformational leadership is mostly about innovation, change, and entrepreneurship. Yukl (1989) [35] defined transformational leadership as a "micro-level and macro-level" influence. To implement transformational leadership, four components are required, which are constituent elements of this theory. They are mentioned below with a brief description:

\subsubsection{Idealized Influence}

It means a leader's certain charismatic actions, which are focused on beliefs, values, and objectivity, and a leader builds respectful relations and trust through 
a high-level ethical behavior (Weese, 1994) [36]. Successful leaders are generally charismatic and they have the capability to attract their followers and teach them (Zdaniuk and Bobocel, 2015) [37].

A manager-leader, who exercises idealized influence on the people, becomes a role model and makes people understand the moral and ideological implications of his/her decisions through showing his/her willingness to sacrifice personal interests for organizational development, and by emphasizing a collective sense of mission. It implies that leaders, who demonstrate higher spiritual standards, morals, and respect for inculcating the sense of loyalty among the followers (Fry, 2003) [38]. This type of leaders are normally trusted and respected, and their followers like to be identified by their leaders and emulate them. Since they prefer meeting their followers' needs before their own, this makes them credible among their followers. On the other hand, a leader shares risks, which followers face, and apply certain principles, ethics, and values (Chaleff, 2009) [39]. Thus, leaders should encourage followers to show higher self-determination levels in their jobs.

\subsubsection{Inspirational Motivation}

This leadership dimension has a broad futuristic vision, which is value-based and reflects their aspirations through arousing excitement, confidence, and enthusiasm among their followers using persuasive language and taking significant symbolic actions (Rijal, 2010) [40]. It includes methods, which leaders apply to excite their followers by putting forward their goals for their optimistic vision for the future. Leaders generally motivate their followers when they present their optimism for the future, by putting forward their achievable vision, and emphasizing ambitious goals (Antonakis, Avolio and Sivasubramaniam, 2003 [41]; Kurland, Peretz, and Hertz-Lazarowitz, 2010 [42]).

Some leaders, who motivate their followers through inspiration, first create a vivid and inspirational vision for their organizations' future through their specific behaviors towards people, and besides, they appreciate their followers and show an optimistic view of the future, radiate confidence in the achievement of their vision, and enthusiasm for shared topics.

\subsubsection{Intellectual Stimulation}

It implies that some leaders challenge organizational practices and norms through demonstrating creative thinking and encourage their followers to find solutions to problems through developing innovative strategies (Rafferty and Griffin, 2004) [43]. This type of leaders displays a certain behavior, which increases their followers' satisfaction through supporting, guiding, and paying attention to meet the needs of their followers (Avolio, Bass, and Jung, 1999) [44]. Some leaders have the capability to create intellectual stimulation among their followers to see old issues in new ways, which encourage them to legitimize their creativity and think differently. During discussions and conversations, they analyze different angles for problem-solving, and regularly test their approaches to 
understand whether they are still viable. When solving problems, a leader considers different perspectives.

\subsubsection{Individualized Consideration}

This leadership attribute increases the followers' satisfaction because it involves giving support, attention, and advice to meet individuals' needs. When a leader listens to followers' demands and understands their needs, it turns him into a coach/mentor; so, it is a very important characteristic (Hertz-Lazarowitz and Kurland, 2010) [42].

Generally, transformational leadership promotes innovative ideas and behaviors. Both individual consideration and intellectual stimulation help transformational leaders create multiple thinking methods, which help finding new opportunities and providing new solutions for discovering, creating, and adapting to the new realities.

\subsubsection{Contingent Reward}

It involves healthy leader-follower interaction that focuses on appropriate rewards when attainment of agreed objectives is discussed. A leader provides a new strategic vision, which involves sensitivity and understanding of the members' needs, and the leader takes personal risks, and his/her entire plan is highly sensitive to the changing needs of the new environment (Conger and Kanungo, 1998) [45].

\subsection{Basic Concepts behind Organizational Learning and Learned Organization}

\subsubsection{Organizational Learning}

Generally, organizations learn when people learn; so, leaders search for methods, which help them achieve more, faster, and deeper in the form of valuable business learning, and what they learned should be converted into useful services and products, which can compete in the market. It makes an organization's learning to a fundamental qualitative shift because learning makes their activities a source of sustainable competitive advantage. In this review, we will focus on some important things regarding organizational learning and some aspects of learned organizations.

Huber (1991) [46] mentioned that an organization learns by processing information with an objective to collect useful knowledge, and maintain the data. Learning within an organization can be subdivided into four processes while organizational learning is one of them. It is an important behavioral process, which shapes organizational behavior. Behaviorists believe that learning instills a new behavior in an individual because of exposure to social experiences (Dolly and Sharifi, 2009).

Knowledge acquisition is practically implemented through collecting information, information distribution, interpretation, data collection, and organizational memory. During the acquisition process, knowledge is attained. Informa- 
tion distribution is about sharing the attained information, which takes the form a new understanding. The information distribution process is followed by information interpretation before it reaches the last organizational process called organizational memory, which is a method of knowledge storage for making it accessible in the future (Huber, 1991) [46].

Still, for making learning more effective, it should be embedded, and characterized by values, which promote transparency, problem-focus, and accountability. Learning improves the capability of an organization to sustain its performance based on the achieved experience (Lloréns-Montes, García-Morales, and Verdú-Jover, 2008) [47]. Organizational learning has been defined differently, so the definitions show a little convergence as compared to the definitions of leadership (Easterby-Smith and Lyles, 2003) [48]. Different organizational learning researchers have used this term for describing different domains, which include information-processing approaches (Huber, 1991) [46], and successful innovation that has certain factors, which are common for almost all industries but its significance is different for different sectors and individual learning forms (March and Olsen, 1975 [49]; Nonaka, 1994 [50]; Kanbur and Mohamed, 2017 [51]).

The emphasis on strategic renewal is common among all the organizational learning domains because it requires organizations to explore new ways, and fully exploit their learning (March, 1991 [52]; Tushman and O'Reilly, 2002 [53]). There is always tension between exploration of the new knowledge and exploitation of the existing information because they are funded from the same organizational resources (Benner and Tushman, 2003) [54].

Using the same direction March (1991) [52] has described the following two processes: While exploration, an organization carries out variation analysis, research, experimentation, risk-taking, discovery, innovation, and operational flexibility. Exploitation, on the other hand, involves matters, such as choice, refinement, productivity, selection, efficiency, and execution. Since exploration seeks variance and depends on creativity and innovation, it needs reliability, standard procedures to incorporate learning, incremental adaptation, and knowledge transfer (Lewin, Carroll, and Long 1999 [55]; McGrath, 2001 [56]).

The strategic renewal process is consistent with the mentioned views on organizational learning. The generally believed concept of organizational learning is a process of change in action and thought both on collective and individual levels, which is affected by the organizational institutions (Vera and Crossan, 2004) [14]. According to the researchers, it has four processes, including intuition, interpretation, integration, and institutionalization, through which, learning takes place at individual, group, and organizational levels.

The process of learning initiates when leaders have intuition and a subconscious process continues until it becomes conscious during the interpretation stage, when they share their vision with their group members and followers. After getting input from the group members, the overall input is shared on the or- 
ganizational level, when the information is institutionalized by many factors which include the range of organizations, for which, some structures are considered to be relevant in the broader perspective of organizations then, it becomes part of routines, systems, and structure. (IAH Mohamed, 2017) [57].

In this stage many researchers have addressed questions and further information about it is available in the 4I model (Crossan et al., 1999) [58]. Organizational learning helps an organization to gain and collect new knowledge and it is linked with leadership and its aspirations. So far, there is no contradiction between different definitions, which define organizational learning as a concept; however, complementarity exists between the researchers, who explained it and highlighted the transformation of organizational aims into a common vision, which helps further development of its capabilities to survive and grow despite rapidly emerging challenges in the surroundings. An organization almost never learns on its own. Its learning is mainly the learning of its members through training, experience, and interactions, which help them achieve the required induction, focus, analysis, and reasoning. It also helps them build scientific constructs and theoretical frameworks.

\subsubsection{Learned Organization}

It is an organization, which is open to learn what is happening in its surroundings; so, it gains from it, influences it, and gives back to it. Organizations differently respond to changes and challenges, which take place in their internal and external environments. They achieve fulfillment when they provide quality goods and services, and meet their customers' and investors' expectations.

Every organization has unique human resource quality, characteristics, and vision to promote organizational learning for building a learned organization, which is fully capable of competing and continuing its operations despite instability of the environment. Despite challenges, organizations keep on generating new ideas to gain and prolong competitive advantage (Kanter, 2003 [59]; Sessa and London, 2015 [60]).

A learned organization model is the operational model of the post-modern era, because in this era, organizations are facing frequent operational challenges, rapid changes, technology and communication advancements, new knowledge generation, knowledge management issues, and growing interest in smart capital. They need appropriate treatment, human element, trust, and appreciation to handle today's workforce. They also require stimulus to learn and innovate, and participatory vision formulation to develop their strategies and decision-making processes (King, 2009 [61]; Proctor, 2018 [62]).

A learning organization is a concept, which implies that organizations should encourage the learning process and find ways to learn more and better. This concept has large number of sub-concepts and issues pertaining to different scientific fields, including economics, politics, biology, organizational theory, and organizational behavior (West, 1994 [63]; Garavan, 1997 [64]). Based on this, researchers all over the world studied it from different angles and aspects 
while every angle/logic was adopted to further improve it; so, they used more than one term to mention a learning organization, and the mentioned terms include thinking organization, knowing organization, and qualified organization (Alrefaai and Khalil, 2019) [65]. The most important definitions that the researchers have mentioned are presented below:

In the literature, several definitions of a learned organization exist, like the one mentioned by Moilanen (2005) [66], who believes that a learned organization is consciously-managed and it focuses on learning as a fundamental element that comprises visions, goals, and values to continue its daily operations. Senge (2004) [67] believed that a learned organization makes everyone work cooperatively but independently for continuously developing their capabilities for achieving results according to their aspirations.

It also attempts to develop new thought patterns to set collective goals and agree on common aspirations. According to Johnson (2002) [68], a learned organization is actually a skilled organization, which creates and owns knowledge before transferring it to all the hierarchical levels, and then, new technology is adapted according to its requirements. Eaterby Smith (1997) [69] pointed out that the learned organization model is an "ideal model" that focuses on maximizing learning.

We have concluded from the above definitions that learned organizations perform according to their own new administrative and operational philosophies creating and acquiring knowledge, and quickly transferring it to all management levels. A learned organization has realistic organizational goals, which require all workers' participation in achievement of knowledge and improve it with experiences, which the workers gained over time. This type of organization's main advantage is continuously learning capability and grows it from a certain performance level to other and better performance, excellence, and growth levels.

\subsubsection{Relation between Organizational Learning and Learned Organization}

According to Marquardt (2002) [70], the relation between organizational learning and a learned organization is a form of "containment relationship." A learned organization focuses on the educational process, which consistently performs for increasing its members' capabilities to gain flexibility, which leads to creating new thinking methods and models.

Organizational learning primarily focuses on the learning process to improve the members' acquisition of skills, directions, and information, which upgrades the organization and helps its members adapt to new variables, which emerge because of changing environment. In the overall scheme of decisions and plans, organizational learning plays as an essential component (Marquardt, 2002) [70]. Hegan (1998) noted that the learned organization-organizational learning relationship is further clarified using the following result: "There is no correct organizational learning process without any consequence of building it" (Örtenblad, 
2001) [71].

\subsection{Transformational Leadership and Organizational Learning}

Researchers claimed that transformational leadership is a significant source of organizational learning, and the available evidence shows that correlation exists between professional values, leadership styles, satisfaction, performance variables, organizational commitment, and motivation (Bass, 1999) [72]. Some recent discussions on the role of leadership to create an open and psychologically conducive atmosphere, and that are crucial for assuring effective organizational learning (Schein, 1993 [73]; Edmondson and Moingeon, 1999 [74]). Following the same argument, Argyris and Schon (1996) mentioned that there some major issues when a leader tries to create or maintain organizational learning processes, which is mainly people's efforts to protect their "positive self-image."

Lipshitz, Ben-Horin Naot, and Popper (2003) [75] mentioned that learning episodes may be high-quality and low-quality, and leadership plays a major role to separate high-quality learning from the low-quality learning episodes. At this point in time, empirical work is rare and the researchers deal with very few variables pertaining to leadership and organizational learning. Additional leadership aspects, which promote organizational learning, need further analyses and empirical investigations. Organizational learning experts generally focus on different learning forms but do not explain who takes learning initiatives (Gibson and Birkinshaw, 2004 [76]; March 1991 [52]; Rosenkopf and Nerkar, 2001 [77]). A few approaches are available in the literature (Crossan, Lane, and White, 1999) [58], which differentiate learning phenomena; however, they only give hints about the role leaders can play to motivate organizational learning.

Additionally, knowledge-intensive culture has strengthened the relationship between transformational leadership and knowledge management process capability. A few studies measured leadership and used learning variables as possible outcomes of forms of leadership, including transformational leadership (Amitay, Popper, and Lipshitz, 2005) [78].

Researchers used learning in certain settings to examine different leadership roles (Edmondson, 1999) [79]. Some researchers focused on the importance of coaching/mentoring leaders for assuring organizational learning (Senge, 1990) [80]. In many cases, transformational leaders first become role models and affect the organizational learning through encouraging intellectual stimulation, inspiring employees, and individualized considerations (Coad and Berry, 1998) [81].

Raferty \& Griffin (2004) [43] believe that transformational leaders have the capacity to intellectually stimulate their employees; therefore, they are effective because intellectual stimulation is necessary for new idea generation, experimentation and problem-solving, and transformational leaders are positive about all of them. Snell (2001) and before him Slater \& Narver (1995) [82] established that positive association exists between organizational learning and transforma- 
tional leadership. Marquardt (1996) [83], on the other hand, presented a concept called "Keys to Success," which leaders should practice in a learning organization. Amy, A. H. (2005) [84] suggested that leaders become important facilitators for organizational learning to occur. Garvin, Edmondson, and Gino (2008) [85] mentioned that leaders' behaviors strongly influence organizational learning; so, it reinforces the learning on each and every level. While discussing the relation between organizational learning and leadership styles at Saudi banks located in Al-Taif, researchers including Nafei, Khanfar, and Kaifi (2012) [86] revealed that different leadership styles, such as transformational and transactional styles, significantly, directly, and positively affect an organization's learning. On the other hand, Sahaya (2012) [87] reported that both the mentioned leadership styles (transformational and transactional) positively affect learning of an organization. Lam (2002) [88] defined how transformational leadership affects organizational learning in the following words: According to a cross-cultural comparison research, transformational leadership can, in fact, affect the process of organizational learning and achieve it. In addition, Kurland et al. [42] mentioned that transformational leadership positively and significantly affects organizational learning. A clarification by Rijal (2010) [40] also shows that transformational leadership style is strongly and significantly correlated with organizational learning. Muhammad Kashif Imran, Muhammad Ilyas, Usman Aslam and Ubaid-Ur-Rahman (2016) develop an organizational learning model through transformational leadership with indirect effect of knowledge management process capability and interactive role of knowledge-intensive culture. The results are clearly depicting that transformational leadership has significant positive impact on organizational learning and knowledge management process capability, and partially mediates the relationship between transformational leadership and organizational learning. Geo Baby (2016) [89] identify relationship between transformational leadership and learning organizations. The results prove that there is a significant positive impact of the factors of Transformational on learning organization.

Liao, S. H., Chen, C. C., Hu, D. C., Chung, Y. C., \& Liu, C. L. (2017) [90] examined the relationship between learning they found conclude that leadership is closely related to OL also demonstrates that in a severe internal and external environment, leadership does have a direct and positive impact on OL. Also, in the study of Megheirkouni, M. (2017) [91] investigate how the relationship between leadership and organizational learning $g$ at for-profit and non-profit sports organizations, and the impact of these leadership styles on enhancing organizational learning in these sports organizations where the results that management by exception-active in transactional leadership and idealized leadership in transformational leadership seem to be equally important for facilitating organizational learning. The results also revealed significant differences between for-profit and non-profit sports organizations in leadership styles and organizational learning. On the other hand Abazeed, R. A. M. (2018) [92] investigating 
the impact of Transformational leadership style on Organizational learning in the Ministry of communication and information technology in Jordan where the results showed that Idealized Influence, Inspirational Motivation, Intellectual Stimulation, and Individualized Consideration had a significant and positive effect on the organizational learning in the Ministry of communication and information technology in Jordan HASHEMI, Z. H., Saadi, H., \& Movahedi, R. (2019) [93] explain the relationship between transformational leadership and learning organization in Agricultural Jihad Organization of Isfahan Province.

Results of regression analyzes showed that there was significant positive relationship between transformational leadership and learning organization components. Xie, L (2020) [94] addressed in his comparative analysis compares two different leadership styles and presents theoretical and practical implications for scholars and practitioners. In particular, how and which leadership style relates to learning organization by examining a structural model with three latent variables: servant leadership, transformational leadership, and learning organization. The results show that servant leadership has no significant relationship to learning organization, whereas transformational leadership is a strong predictor.

Franz Harry Sánchez Espejo, Edward Flores (2021) [95] determines the impact of knowledge management and teamwork on organizational learning in the Educational Institutions of the Network, the results showed that $53.8 \%$ of teachers surveyed believe that knowledge management is regular, 53\% that teamwork is regular and 59.8\% and that organizational learning is regular. Implying that organizational learning variability depends $77.7 \%$ on knowledge management and teamwork. Therefore, there is influence of knowledge management and teamwork on organizational learning in the Educational Institutions.

\section{Conclusions}

The current study has been conducted for highlighting the significance of the relation between organizational learning and transformational leadership through focusing on the importance of leadership roles in today's continuously changing and challenging business environments. Devoting to organizational learning transforms organizations and companies into informed and learned institutions, which have very knowledgeable workforces. Such organizations can create an environment, which further encourages knowledge exchange and learning from experiences, and create an environment that has positive factors like collectivism and team spirit. This is not possible without fully aware transformational leaders, who understand the significance of continuous learning for the long-term future of an organization operating in the current era. It also helps to improve the company's performance to new levels.

According to the results, transformational leadership positively affects organizational learning, which has a direct impact on improving innovation and creativity. Despite some evidence in the literature, there is a need to further investigate the mentioned results in different types of organizations located in dif- 
ferent parts of the world. It is recommended that senior managers make efforts to adopt latest leadership styles and they should extend support to transformational leaders to assure that the organizational learning programs are effective. They focus on the most creative and innovative aspects of their people and the learning process. Transformational leaders should be given top organizational positions for creating the required change. It also helps them move towards better organizational culture and better learning, which are considered as the initial steps towards innovation and tapping the employees' creative potential. In the future research, it is recommended to conduct future research by taking Knowledge management as a mediator between Transformational Leadership and organizational learning.

\section{Conflicts of Interest}

The authors declare no conflicts of interest regarding the publication of this paper.

\section{References}

[1] Hogan, R. and Kaiser, R.B. (2005) What We Know about Leadership. Review of General Psychology, 9, 169-180. https://doi.org/10.1037/1089-2680.9.2.169

[2] Bass, B.M. (1990) From Transactional to Transformational Leadership: Learning to Share the Vision. Organizational Dynamics, 18, 19-31. https://doi.org/10.1016/0090-2616(90)90061-S

[3] Hübner, S. (1995) Building a Learning Organization. Harvard Business Review, 75, 148.

[4] Prokesch, S.E. (1997) Unleashing the Power of Learning: An Interview with British Petroleum's John Browne. Harvard Business Review, 75, 146-162.

[5] Brix, J. (2017) Exploring Knowledge Creation Processes as a Source of Organizational Learning: A Longitudinal Case Study of a Public Innovation Project. Scandinavian Journal of Management, 33, 113-127. https://doi.org/10.1016/j.scaman.2017.05.001

[6] Knopf, J.W. (2003) The Importance of International Learning. Review of International Studies, 29, 185-207. https://doi.org/10.1017/S0260210503001852

[7] Weed-Schertzer, B. (2020) Tools for Knowledge and Organizational Learning. In: (II) Logical Knowledge Management, Emerald Publishing Limited, Bingley, 83-117. https://doi.org/10.1108/978-1-83867-803-620201003

[8] İşcan, Ö.F., Ersarı, G. and Naktiyok, A. (2014) Effect of Leadership Style on Perceived Organizational Performance and Innovation: The Role of Transformational Leadership beyond the Impact of Transactional Leadership-An Application among Turkish SME's. Procedia-Social and Behavioral Sciences, 150, 881-889. https://doi.org/10.1016/j.sbspro.2014.09.097

[9] Chatbury, A., Beaty, D. and Kriek, H.S. (2011) Servant Leadership, Trust and Implications for the "Base-of-the-Pyramid" Segment in South Africa. South African Journal of Business Management, 42, 5761. https://doi.org/10.4102/sajbm.v42i4.505

[10] Zaleznik, A. (1977) Managers and Leaders: Are They Different.

[11] Bedeian, A.G. and Hunt, J.G. (2006) Academic Amnesia and Vestigial Assumptions of Our Forefathers. The Leadership Quarterly, 17, 190-205. 
https://doi.org/10.1016/j.leaqua.2005.12.006

[12] Yukl, G.A. and Becker, W.S. (2006) Effective Empowerment in Organizations. Organization Management Journal, 3, 210-231. https://doi.org/10.1057/omj.2006.20

[13] House, R.J. and Aditya, R.N. (1997) The Social Scientific Study of Leadership: Quo Vadis? Journal of Management, 23, 409-473. https://doi.org/10.1177/014920639702300306

[14] Vera, D. and Crossan, M. (2004) Strategic Leadership and Organizational Learning. Academy of Management Review, 29, 222-240.

https://doi.org/10.5465/amr.2004.12736080

[15] Bass, B.M. (1985) Leadership: Good, Better, Best. Organizational Dynamics, 13, 26-40. https://doi.org/10.1016/0090-2616(85)90028-2

[16] Dinh, J.E., Lord, R.G., Gardner, W.L., Meuser, J.D., Liden, R.C. and Hu, J. (2014) Leadership Theory and Research in the New Millennium: Current Theoretical Trends and Changing Perspectives. The Leadership Quarterly, 25, 36-62. https://doi.org/10.1016/j.leaqua.2013.11.005

[17] Robbins, S.P. and Judge, T. (2003) Essentials of Organizational Behavior (Vol. 7). Prentice Hall, Upper Saddle River.

[18] Raes, E., Decuyper, S., Lismont, B., Van den Bossche, P., Kyndt, E., Demeyere, S. and Dochy, F. (2013) Facilitating Team Learning through Transformational Leadership. Instructional Science, 41, 287-305. https://doi.org/10.1007/s11251-012-9228-3

[19] Zhang, T. (2011) The Relationship between Perceived Leadership Styles and Employee Engagement: The Moderating Role of Employee Characteristics.

[20] Robbins, P. and O'Gorman, C. (2012) Team Leadership and Managing for Innovation: A Case Study of Competing Teams in a Global Firm. ISPIM Conference Proceedings, Manchester, 28 January 2012, 1.

[21] Leithwood, K. and Sun, J. (2012) The Nature and Effects of Transformational School Leadership: A Meta-Analytic Review of Unpublished Research. Educational Administration Quarterly, 48, 387-423. https://doi.org/10.1177/0013161X11436268

[22] Jiang, W., Gu, Q. and Wang, G.G. (2015) To Guide or to Divide: The Dual-Side Effects of Transformational Leadership on Team Innovation. Journal of Business and Psychology, 30, 677-691. https://doi.org/10.1007/s10869-014-9395-0

[23] Achua, C.F. and Lussier, R.N. (2013) Effective Leadership. South-Western Cengage Learning, Mason.

[24] Daft, R.L. (2008) The Leadership Experience. South-Western, Cincinnati.

[25] Yukl, G. (2011) Contingency Theories of Effective Leadership. The SAGE Handbook of Leadership, 24, 286-298.

[26] Lewin, K., Lippitt, R. and White, R.K. (1939) Patterns of Aggressive Behavior in Experimentally Created "Social Climates". The Journal of Social Psychology, 10, 269-299. https://doi.org/10.1080/00224545.1939.9713366

[27] Antonakis, J., Cianciolo, A.T., Sternberg, R.J., Bass, B., Bass, R., Bryman, A. and Jackson, B. (2011) Resources for Studying Leadership. In: A Very Short Fairly Interesting and Reasonably Cheap Book about Studying Leadership, SAGE Publications Ltd., London, 152.

[28] Fiedler, F.R.E.D. (2015) Contingency Theory of Leadership. In: Organizational Behavior 1: Essential Theories of Motivation and Leadership, Routledge, London, 232.

[29] Barbuto, J.E. (1997) Taking the Charisma Out of Transformational Leadership. 
Journal of Social Behavior and Personality, 12, 689-697.

[30] Khanin, D. (2007) Contrasting Burns and Bass: Does the Transactional-Transformational Paradigm Live Up to Burns' Philosophy of Transforming Leadership? Journal of Leadership Studies, 1, 7-25. https://doi.org/10.1002/jls.20022

[31] Sadeghi, A. and Pihie, Z.A.L. (2012) Transformational Leadership and Its Predictive Effects on Leadership Effectiveness. International Journal of Business and Social Science, 3, 186-197.

[32] Avolio, B.J. and Bass, B.M. (1995) Individual Consideration Viewed at Multiple Levels of Analysis: A Multi-Level Framework for Examining the Diffusion of Transformational Leadership. The Leadership Quarterly, 6, 199-218. https://doi.org/10.1016/1048-9843(95)90035-7

[33] Odumeru, J.A. and Ogbonna, I.G. (2013) Transformational vs. Transactional Leadership Theories: Evidence in Literature. International Review of Management and Business Research, 2, 355.

[34] Tichy, N.M. and Devanna, M.A. (1986) The Transformational Leader. Training \& Development Journal, 40, 27-32.

[35] Yukl, G. (1989) Managerial Leadership: A Review of Theory and Research. Journal of Management, 15, 251-289. https://doi.org/10.1177/014920638901500207

[36] Weese, W.J. (1994) A Leadership Discussion with Dr. Bernard Bass. Journal of Sport Management, 8, 179-189. https://doi.org/10.1123/jsm.8.3.179

[37] Zdaniuk, A. and Bobocel, D.R. (2015) The Role of Idealized Influence Leadership in Promoting Workplace Forgiveness. The Leadership Quarterly, 26, 863-877. https://doi.org/10.1016/j.leaqua.2015.06.008

[38] Fry, L.W. (2003) Toward a Theory of Spiritual Leadership. The Leadership Quarterly, 14, 693-727. https://doi.org/10.1016/j.leaqua.2003.09.001

[39] Chaleff, I. (2009) The Courageous Follower: Standing Up to \& for Our Leaders. Berrett-Koehler Publishers, Oakland.

[40] Rijal, S. (2010) Leadership Style and Organizational Culture in Learning Organization: A Comparative Study. International Journal of Management \& Information Systems (IJMIS), 14, 119-128. https://doi.org/10.19030/ijmis.v14i5.19

[41] Antonakis, J., Avolio, B.J. and Sivasubramaniam, N. (2003) Context and Leadership: An Examination of the Nine-Factor Full-Range Leadership Theory Using the Multifactor Leadership Questionnaire. The Leadership Quarterly, 14, 261-295. https://doi.org/10.1016/S1048-9843(03)00030-4

[42] Kurland, H., Peretz, H. and Hertz-Lazarowitz, R. (2010) Leadership Style and Organizational Learning: The Mediate Effect of School Vision. Journal of Educational Administration, 48, 7-30. https://doi.org/10.1108/09578231011015395

[43] Rafferty, A.E. and Griffin, M.A. (2004) Dimensions of Transformational Leadership: Conceptual and Empirical Extensions. The Leadership Quarterly, 15, 329-354. https://doi.org/10.1016/j.leaqua.2004.02.009

[44] Avolio, B.J., Bass, B.M. and Jung, D.I. (1999) Re-Examining the Components of Transformational and Transactional Leadership Using the Multifactor Leadership. Journal of Occupational and Organizational Psychology, 72, 441-462. https://doi.org/10.1348/096317999166789

[45] Conger, J.A. and Kanungo, R.N. (1998) Charismatic Leadership in Organizations. Sage Publications, London.

[46] Huber, G.P. (1991) Organizational Learning: The Contributing Processes and the Literatures. Organization Science, 2, 88-115. https://doi.org/10.1287/orsc.2.1.88 
[47] García-Morales, V.J., Lloréns-Montes, F.J. and Verdú-Jover, A.J. (2008) The Effects of Transformational Leadership on Organizational Performance through Knowledge and Innovation. British Journal of Management, 19, 299-319. https://doi.org/10.1111/j.1467-8551.2007.00547.x

[48] Easterby-Smith, M. and Lyles, M. (2003) Re-Reading Organizational Learning: Selective Memory, Forgetting, and Adaptation. Academy of Management Perspectives, 17, 51-55. https://doi.org/10.5465/ame.2003.10025192

[49] March, J.G. and Olsen, J.P. (1975) The Uncertainty of the Past: Organizational Learning under Ambiguity. European Journal of Political Research, 3, 147-171. https://doi.org/10.1111/j.1475-6765.1975.tb00521.x

[50] Nonaka, I. (1994) A Dynamic Theory of Organizational Knowledge Creation. Organization Science, 5, 14-37. https://doi.org/10.1287/orsc.5.1.14

[51] Kanbur, A. and Mohamed, İ.A. (2017) Whether Open Innovation Is a Better Choice as a Model of Innovation for Organizations.

[52] March, J.G. (1991) Exploration and Exploitation in Organizational Learning. Organization Science, 2, 71-87. https://doi.org/10.1287/orsc.2.1.71

[53] Tushman, M., Tushman, M.L. and O’Reilly, C.A. (2002) Winning through Innovation: A Practical Guide to Leading Organizational Change and Renewal. Harvard Business Press, Cambridge.

[54] Benner, M.J. and Tushman, M.L. (2003) Exploitation, Exploration, and Process Management: The Productivity Dilemma Revisited. Academy of Management Review, 28, 238-256. https://doi.org/10.5465/amr.2003.9416096

[55] Lewin, A.Y., Long, C.P. and Carroll, T.N. (1999) The Coevolution of New Organizational Forms. Organization Science, 10, 535-550.

https://doi.org/10.1287/orsc.10.5.535

[56] McGrath, R.G. (2001) Exploratory Learning, Innovative Capacity, and Managerial Oversight. Academy of Management Journal, 44, 118-131. https://doi.org/10.2307/3069340

[57] Mohamed, I.A. (2017) Some Issues in the Institutional Theory: A Critical Analysis. International Journal of Scientific and Technology Research, 6, 150-156.

[58] Crossan, M.M., Lane, H.W. and White, R.E. (1999) An Organizational Learning Framework: From Intuition to Institution. Academy of Management Review, 24, 522-537. https://doi.org/10.5465/amr.1999.2202135

[59] Kanter, R.M. (2003) Challenge of Organizational Change: How Companies Experience It and Leaders Guide It. Simon and Schuster, New York.

[60] Sessa, V.I. and London, M. (2015) Continuous Learning in Organizations: Individual, Group, and Organizational Perspectives. Psychology Press, Hove. https://doi.org/10.4324/9781315820941

[61] King, W.R. (2009) Knowledge Management and Organizational Learning. In: Knowledge Management and Organizational Learning, Springer, Boston, 3-13. https://doi.org/10.1007/978-1-4419-0011-1_1

[62] Proctor, T. (2018) Creative Problem Solving for Managers: Developing Skills for Decision Making and Innovation. Routledge, London. https://doi.org/10.4324/9780429458255

[63] West, P. (1994) The Concept of the Learning Organization. Journal of European Industrial Training, 18, 15-21. https://doi.org/10.1108/03090599410054308

[64] Garavan, T. (1997) The Learning Organization: A Review and Evaluation. The Learning Organization, 4, 18-29. https://doi.org/10.1108/09696479710156442 
[65] Alrefaai, M.R. and Khalil, A.H.A. (2019) The Impact of Knowledge Management on the Learning.

[66] Moilanen, R. (2005) Diagnosing and Measuring Learning Organizations. The Learning Organization, 12, 71-89. https://doi.org/10.1108/09696470510574278

[67] Senge, P. (2004) Building Learning Organizations. Knowledge Management.

[68] Johnson, J.R. (2002) Leading the Learning Organization: Portrait of Four Leaders. Leadership \& Organization Development Journal, 23, 241-249. https://doi.org/10.1108/01437730210435956

[69] Easterby-Smith, M. (1997) Disciplines of Organizational Learning: Contributions and Critiques. Human Relations, 50, 1085-1113. https://doi.org/10.1177/001872679705000903

[70] Marquardt, M.J. (2002) Building the Learning Organization: Mastering the 5 Elements for Corporate Learning. Nicholas Brealey Publishing, Hachette.

[71] Örtenblad, A. (2001) On Differences between Organizational Learning and Learning Organization. The Learning Organization, 8, 125-133. https://doi.org/10.1108/09696470110391211

[72] Bass, B.M. (1999) Two Decades of Research and Development in Transformational Leadership. European Journal of Work and Organizational Psychology, 8, 9-32. https://doi.org/10.1080/135943299398410

[73] Schein, E.H. (1993) On Dialogue, Culture, and Organizational Learning. Organizational Dynamics, 22, 40-51. https://doi.org/10.1016/0090-2616(93)90052-3

[74] Edmondson, A. and Moingeon, B. (1999) Learning, Trust and Organizational Change: Contrasting Models of Intervention Research in Organizational Behaviour. In: Easterby-Smith, M., Burgoyne, J. and Araujo, L., Eds., Organizational Learning and the Learning Organization: Developments in Theory and Practice, Sage, London, 157-175.

[75] Ben-Horin Naot, Y., Lipshitz, R. and Popper, M. (2003) High-Quality Organizational Learning: A Grounded Theory Approach. 5th Organizational Learning \& Knowledge Conference, Lancaster, 30.

[76] Birkinshaw, J. and Gibson, C.B. (2004) Building an Ambidextrous Organization. Advanced Institute of Management Research Paper, (003).

https://doi.org/10.2139/ssrn.1306922

[77] Rosenkopf, L. and Nerkar, A. (2001) Beyond Local Search: Boundary-Spanning, Exploration, and Impact in the Optical Disk Industry. Strategic Management Journal, 22, 287-306. https://doi.org/10.1002/smj.160

[78] Amitay, M., Popper, M. and Lipshitz, R. (2005) Leadership Styles and Organizational Learning in Community Clinics. The Learning Organization, 12, 57-70. https://doi.org/10.1108/09696470510574269

[79] Edmondson, A. (1999) Psychological Safety and Learning Behavior in Work Teams. Administrative Science Quarterly, 44, 350-383. https://doi.org/10.2307/2666999

[80] Senge, P.M. (1990) The Art and Practice of the Learning Organization.

[81] Coad, A.F. and Berry, A.J. (1998) Transformational Leadership and Learning Orientation. Leadership \& Organization Development Journal, 19, 164-172. https://doi.org/10.1108/01437739810210211

[82] Slater, S.F. and Narver, J.C. (1995) Market Orientation and the Learning Organization. Journal of Marketing, 59, 63-74. https://doi.org/10.1177/002224299505900306

[83] Marquardt, M.J. (1996) Building the Learning Organization: A Systems Approach 
to Quantum Improvement and Global Success. McGraw-Hill Companies, London.

[84] Amy, A.H. (2005) Leaders as Facilitators of Organizational Learning. Regent University, Virginia Beach.

[85] Garvin, D.A., Edmondson, A.C. and Gino, F. (2008) Is Yours a Learning Organization? Harvard Business Review, 86, 109.

[86] Nafei, W.A., Khanfar, N.M. and Kaifi, B.A. (2012) Leadership Styles and Organizational Learning an Empirical Study on Saudi Banks in Al-Taif Governorate Kingdom of Saudi Arabia. Journal of Management and Strategy, 3, 2.

https://doi.org/10.5430/jms.v3n1p2

[87] Sahaya, N. (2012) A Learning Organization as a Mediator of Leadership Style and Firms' Financial Performance. International Journal of Business and Management, 7, 96. https://doi.org/10.5539/ijbm.v7n14p96

[88] Lam, Y.J. (2002) Defining the Effects of Transformational Leadership on Organizational Learning: A Cross-Cultural Comparison. School Leadership \& Management, 22, 439-452. https://doi.org/10.1080/1363243022000053448

[89] Baby, G. and Varghese, K.G. (2016) Transformational Leadership and Learning Organization: A Study with Special Reference to the Organizational Leadership in Kerala. Doctoral Dissertation, Cochin University of Science and Technology, Kochi.

[90] Liao, S.H., Chen, C.C., Hu, D.C., Chung, Y.C. and Liu, C.L. (2017) Assessing the Influence of Leadership Style, Organizational Learning and Organizational Innovation. Leadership \& Organization Development Journal, 38, 590-609. https://doi.org/10.1108/LODJ-11-2015-0261

[91] Megheirkouni, M. (2017) Leadership Styles and Organizational Learning in UK For-Profit and Non-Profit Sports Organizations. International Journal of Organizational Analysis, 25, 596-612. https://doi.org/10.1108/IJOA-07-2016-1042

[92] Abazeed, R.A.M. (2018) Impact of Transformational Leadership Style on Organizational Learning in the Ministry of Communication and Information Technology in Jordan. International Journal of Business and Social Science, 9, 118-129.

[93] Hashemi, Z.H., Saadi, H. and Movahedi, R. (2019) The Relationship between Transformational Leadership and Learning Organization (Case Study: Agricultural Jihad Organization of Isfahan Province).

[94] Xie, L. (2020) The Impact of Servant Leadership and Transformational Leadership on Learning Organization: A Comparative Analysis. Leadership \& Organization Development Journal, 41, 220-236. https://doi.org/10.1108/LODJ-04-2019-0148

[95] Espejo, F.H.S. and Flores, E. (2021) Knowledge Management and Teamwork in Organizational Learning in Educational Institutions of Network No. 02, Lima. Psychology and Education Journal, 58, 5245-5259. 